\title{
EU Governance: Struggle between Cooperation and Competition*
}

\section{N. Nevra Esentürk*}

\begin{abstract}
EU governance is characterized as a multi-level system in which various actors are involved in the policy-making procedure at multiple levels in a non-hierarchical way.During the course of the European integration process, EU governance has been brought forward as a response to the citizens' quest for a legitimacy through enhanced democratization in the decision-making mechanisms and as a tool that would increase the leverage and competitiveness of the EU to have an efficient way of functioning for the enlargement of the Union. In that respect, the legitimacy and the representative power of the EU and its institutions are put under scrutiny, as powerful and at the same time efficient decision-making mechanisms are necessary for the EU. However, although significant changes are enshrined in the Lisbon Treaty regarding the decision-making procedure and policy outcomes, it has been limited with struggle between cooperation and competition at vertical and horizontal levels under the shadow of supranational hierarchy that has created mistrust on the EU institutions and decision-making structures from the perspective of citizens. The article addresses this issue on the grounds of the reasons and the circumstances in which EU governance emerged, the principles and characteristics it is based on, the means and ways it utilizes, and the effects on the decisionmaking process of the EU.
\end{abstract}

Key Words: European Union, EU governance, EU institutional structure, EU decision-making procedure

\footnotetext{
* An earlier version of this study was presented at European International Studies Association (EWIS), on the 2nd European Workshops in International Studies, İzmir, 21-24th May 2014.

* Asst. Prof. Dr., Department of International Relations, Yalova University, Turkey.
} 


\section{N. Nevra Esentürk}

\section{Introduction}

Developments taking place in the international arena, especially after the Second World War had fundamental effects on the transformation and in the comprehension and explanation of the facts in the European integration process. European integration, which had commenced at the state level I based on cooperation among the member states, was transformed towards the European level through supranational authorities. In the light of international developments, it can be seen that not only states, but also other actors intervene in the process of integration. These actors such as nongovernmental organizations (NGOs), social partners, independent experts and interest groups have increased their influence in the process of European integration day by day through the governance in the EU.

In this system of governance, which has drawn attention to the interaction among states at different levels, not only the governmental but also at the level of NGOs, the focus has been on multi-level governance, in which there is a complex web of relations in the policy-making process of the EU. ${ }^{1}$ The governance approach overall has swept away the perception that the state is the only compatible entity then on. Thus, the dichotomy between low politics and high politics in classical international relations theories are criticized as the distinction between them has become meaningless. However, this does not mean that the significance of nation states is undermined. As it is pointed out by Hooghe and Marks, "nation states are still an integral and powerful part of the EU, but they no longer provide the sole interface between supranational and sub national arenas". They control over many areas, activities and actions.

Under these changed conditions in the world arena spurred with globalization, there necessitates interdependence across boundaries, collective action to provide common goods that has to take place vertically across multiple levels of government and horizontally across multiple arenas involving public and private corporate actors. ${ }^{3}$ In this international context, no single actor, public or private, has sufficient potential for action and/or sufficient power to solve problems of interdependence on her own, nor has she all the knowledge and information required to solve complex, dynamic and diversified international problems. ${ }^{4}$ In this changed international context, Europe is such a multi-level and multi-arena polity, and is faced with such complex problems of interdependence against a background of diverse social and economic conditions that public and private actors with very diverse interests depend on each other to provide common goods. In short, it is faced with a need for multi-level governance which has opened up opportunities for public and private interests of all kinds to enter the policy-making process. ${ }^{5}$

EU governance has been brought forward as a response to the citizens' quest for a legitimacy through enhanced democratization in the decision-making mechanisms and as a tool that would increase the leverage and competitiveness of the EU to have an efficient way of functioning for the enlargement of the Union. In that respect, the legitimacy and the representative power of the EU and its institutions are put under scrutiny, as powerful and at the same time efficient decisionmaking mechanisms are necessary for the EU. However, although significant changes are enshrined in the Lisbon Treaty regarding the decision-making procedure and policy outcomes, it has been limited with struggle between cooperation and competition at vertical and horizontal levels under the shadow of supranational hierarchy that has created mistrust on the EU institutions and decisionmaking structures from the perspective of citizens. The article addresses this issue on the grounds of the reasons and the circumstances in which EU governance emerged, the principles and characteristics it is based on, the means and ways it utilizes, and the effects on the decision-making process of the EU. 


\section{EU Governance}

\section{Origins of EU Governance}

During the evolution of the European integration process, starting in the 1980s and especially in the 1990s, and depending on the formation of a multi-level, complex, institutional EC, there has been a combination of supranational and intergovernmental elements, and a strong role for the judiciary. ${ }^{6}$ In line with this, we came across with the emergence of governance approach in the EU . Concerning these specific developments, the SEA put into practice in the second half of the 1980s is to be the turning point for the trigger of developments for the emergence of the governance in that starting with the SEA, the delegation of competences to the EC level was increased, which strengthened the power of the EC. In other words, these limits on member states' control with the introduction of Qualified Majority Voting (QMV) through the SEA opened the way forward towards collective decision-making, despite the fact that the areas in which QMV was put into practice were limited and non-sensitive in content. With the Maastricht Treaty, the EU has become an entity for political issues as well. Thus, with this step by step development of Treaty revisions mentioned above, the internal dynamics of the EU, especially in various parts of policy-making has become crucially important in the European integration phenomenon, although there are mixed competences between national and European level in certain specific policy sectors in the complicated process of policy-making in the EU.

In addition to the Treaty based dynamics of the EU, the internal political dynamics of the EU had a notable impact on the way towards the increasing applicability of governance in the EU. In that respect, the resignation of the Santer Commission in 1999 can be given as an illustration. This development was a turning point in the history of European integration in that it prompted a wider review of the future shape of the EU. ${ }^{7}$ In this framework, from autumn 2000, the political momentum of the reform process was sustained and it was given operational form by the preparation of a Commission White Paper on European Governance, published in the summer of 2001. Not only does the White Paper place reforming the Commission in the broader perspective of the functioning of a system of multilevel governance, but also it highlights the neglected issue of ensuring effective performance in the EU as a whole. ${ }^{8}$ Thus, it can be said that the fall of the Santer Commission seemed to transform the political climate from 'reform impossible' to 'reform inevitable', which have had a decisive influence on the future development of European integration.

\section{On the Way towards EU Governance}

With the trigger of the abovementioned developments, changes have occurred in the way the EU is governed. Governance, which is based on the internal functioning of the EU, that is, policy-making in the EU, tries to explain the effects of European integration. The basic changes are a multi-layered system in which multiple actors intervene in the process through multiple venues of policy-making. In other words, as Hooghe and Marks put forward, "there is a non-hierarchical organization in this system where at different levels, both at the national level (national bureaucrats, experts) and subnational level (representatives of interest groups) several actors intervene in the process of policy-making, resulting in interaction between different levels of authority". ${ }^{9}$ In such an apolitical system, ideologies are not that important. It is based on deliberative interaction and negotiation among different levels of actors. However, considering the institutional structure of the EU, there has always been struggle between this cooperation and competition among different levels of actors.

Governance within this new system is described by Hix as 'sui generis', through a unique set of multi-level, non-hierarchical and regulatory institutions, and a hybrid mix of state and non-state actors. ${ }^{10}$ The main principles that the governance system in the EU is based on are summarized by Hix as "the process of governing involving not only the exclusive conduct of the state but also all the activities of social, political and administrative actors under the non-hierarchical and dependent relationship between state and non-state actors for the key governance function of 'regulation' of 


\section{N. Nevra Esentürk}

social and political risk to produce a new 'problem-solving' rather than bargaining style of decisionmaking"11.

Based on these principles, it is argued that member states are still very important in the entire system. ${ }^{12}$ Thus, the distribution of policy-making powers between the European and member state levels is more one of power-sharing between different levels with the member states that retain a very substantial role in decision-making. The resulting picture displays the specific feature of the EU's institutional structure, the politics of which is not characterized by hierarchical decisionmaking and implementation but by negotiations among independent actors and institutions. ${ }^{13}$ The decisions which have to respect member state autonomy would prevent the resolution of collective action problems among EU member states evoking interest in a general orientation of decisionmaking that is compatible with Union-wide policies. ${ }^{14}$

\section{Complexity of EU Governance}

Considering the decision-making process of the EU, how the institutions of the EU function in governance is another important question to bring up the issue of functioning of governance in terms of complex web of relation among the actors in the decision-making procedure.. In a general overview of the institutional structure of the EU, starting from the very beginning of the integration process, it is seen that during the development of the EU Treaties, there has been a process of selective delegation of administrative powers from member state level to the supranational level. Thus, the transformation from state-centric to multi-level governance was one of the prominent topics of discussion during the development of European integration process, which is related very much with the functioning of the institutional structure of the EU to the extent it was affected from governance in the EU during the European integration process.

With regards to EU governance as a model progressing continuously at complex and multilevel, not only the basic EU institutions of the European Commission, European Parliament, the Council of the EU, the European Court of Justice, but also EU governments, ministries, national legal systems as well as sub-national administrations are included. In addition, it incorporates the units in the decision-making mechanism such as agencies, representatives and interest groups. In this section, basic the functions basic EU institutions as well as interest groups are discussed to bring fore complex nature of EU governance in which the political decisions and politics are taken at different levels with a continuous mutual interaction among them.

\section{The European Commission as the Initiator of the Decision-making Process}

The dichotomy between state level and multi-level governance has been at the foreground since the 1990s onwards in the European integration process. The unique institutional structure of the EU has also played an important part in this issue. Among the main actors of the institutional structure of the European Union, it is wise to commence the discussion with the main supranational institution of the EU, the European Commission. The Commission has the crucial tasks of being the guardian of the Treaties, and has the rule-making and monitoring functions for the national implementation of member states. However, among these responsibilities of the Commission, the main one in relation to policy-making in the EU is that the Commission is the initiator of the decision-making process. The Commission has the formal power to initiate and draft legislation including the right to amend or withdraw its proposal at any stage in the process. It also acts similarly to a think tank for new policies which are illustrated in reports, white papers, green papers, other studies and communications that the Commission produces. ${ }^{15}$

Although it has just been emphasized that the Commission is the initiator of the decisionmaking process, in the sui generis picture of EU institutional structure, the Commission with a 


\section{EU Governance}

significant agenda setting power does not function on its own. The Commission has the power and ability to do the job, but it is subject to pressures from many actors. Thus, policy initiation in the EU is a multi-actor activity, including not only the Commission, but also the European Council, the Council of Ministers, and interest groups alongside individual member states. ${ }^{16}$ Within the framework of the governance approach, the European social partners have emerged as one of the significant actors that cooperate with other non-state actors as well as with the EU institutions, particularly the European Commission.

The organizational set-up of the Commission illustrates that the Commission works together with multiple actors. Within the framework of organization of the Commission, together with the core executive of the College of Commissioners who are responsible for all the acts of the Commission, and the bureaucracy is composed of Directorate Generals (DGs) in which the main tasks are carried out. In addition, there is a network of agencies that work in parallel with the Commission. These are quasi-autonomous agencies that do not have decision-making powers but conduct extensive work in related policy areas. Their agents have their interest and preferences of their own. They provide feedback, research for the Commission and back up the work of the Commission. Thus, it has interaction with multiple actors and interest groups they try to affect the agency. Then, the Commission has become subject to the maneouver of the interest groups. Eurocrats are trying to increase their influence in the political process. They want to increase the budget, sources, staff, the profile and reputation of certain agencies. They want to increase their leverage over the political actors. This is something called 'bureaucratic drift'. For instance, concerning the social dimension if the president of the Commission, Jacques Delors did not intervene, the Social Charter would not have been approved in 1989. The Commission tries to stir a middle way that may shift the policy outcome to certain limits.

As an executive power, the Commission also has a political function as the leader of society. Throughout the proposal of the policy and legislation, it has political function for economic and social issues and home and security affairs. For the preparation of policy and legislation, the Commission is engaged in widespread contact with the committees. There has been widespread negotiation, cooperation and a network of advisory committees which give support to the bureaucracy of the Commission. There are expert committees in which national experts act on their knowledge. For social affairs, the Foundation for the Improvement of Living and Working Conditions (EUROFOUND) can be given as an example. Moreover, there are consultative committees in which representatives of sectoral interests present their own approach. There is an informal process going on between the Council and the Commission before the initiation of the legislation. In that respect, the Commission works closely with the Council and national bureaucrats. There is a greater cooperation between the Commission and the European Council, while the former is creative; the latter one is much more reactive.

However, the Commission has some weaknesses in that it has a limited capacity which is dependent on delegation granted by the member states. ${ }^{17}$ Other than agriculture, competition and external trade, the Commission relies upon member state submissions, its extensive advisory system of public and private actors, and paid consultants. The Commission is flooded with work. It has a very rigid and hierarchical framework which makes communication within the Commission difficult. ${ }^{18}$ Differences in policy styles and differences among multi-national environments may be problematic for internal communication in the Commission. ${ }^{9}$

All legislatures have a system of delegating detailed implementing measures to the executive. At European level, the EP and the Council of the European Union can confer such powers on the Commission via the comitology procedure. In that respect, comitology, which involves committees composed of the representatives of the governments of the member states at the level of civil servants, is a vital part of the adoption and implementation of Community law. Most EC acts, many of great importance, are taken by the Commission under powers delegated by the Council, and in such cases there is no formal involvement of the general public, national parliaments or the European Parliament. ${ }^{20}$ Through the comitology procedure, the Council keeps the Commission under control, as in the committees the Commission must act in conjunction with representatives of member states who often have the power to block the Commission and refer the 


\section{N. Nevra Esentürk}

matter to the Council. In that sense, comitology can be regarded as 'interface of dual executive power' ${ }^{21}$.

The comitology decision was initially adopted in 1987, which was later amended in 1999 and in 2006. The initial comitology decision set out standard types of committees of national representatives which assist the Commission in the exercise of powers conferred upon it by the Council. ${ }^{22}$ With the amendment adopted in 1999, three implementation committees were set out, namely advisory, management, regulatory. ${ }^{23}$ Advisory committees give opinions which the Commission must take account of, but it retains the power of decision. Management committees can block a proposed Commission measure by a qualified majority. A regulatory committee needs a qualified majority to approve a proposed Commission measure. Moreover, under the new procedure agreed in 2006 , in addition to the committees set out, regulatory committee with scrutiny was established. ${ }^{24}$ According to this new procedure, measures not adopted are referred to the Council for a decision or Council and Parliament under the new regulatory committee with scrutiny. ${ }^{25}$ In that case, opposition from either will block the proposed measure.

In line with this evaluation of the European Commission in terms of EU governance, there emerges the question of whether the European Commission makes a real difference in exerting significant autonomous influence over the agents, as a multi-level governance perspective would suggest. ${ }^{26}$ This question is still on the agenda with no clear-cut answers. Upon the dichotomy that has continued going since the initial phases of European integration, there is fusion between the national and supranational levels in the institutional structure. However, they should not be completely considered as two opposing folds, as they come up with consensus and negotiations within the framework of a culture of cooperation. Despite the fact that direct constraints on the Commission originate from the European Parliament and the Council of Ministers, the power of initiative has increasingly become a shared competence, permanently subject to contestation, among the three institutions. ${ }^{27}$

The Commission also actively supports interest groups, provides financial assistance to them, which brings about their demand for the maximization of their strength and responsibilities in the policy-making procedure. During the preparation of policy and legislation, the Commission is engaged in widespread contact with committees such as consultative committees, expert committees that would provide technical expertise, widespread negotiation, policy networks and coalitions. With these instruments, the Commission deliberates governance in the EU and acts as a supervisor and facilitator of the involvement of various actors in the policy-making procedure. In that respect, the Commission has some amount of autonomy and socialization within the limits of the delegation of powers conferred by the member states.

\section{The Council of the EU as the Intergovernmental Body of the $E U$}

The Council of the EU is the other main institution of the EU constituting the other end of the continuum, the intergovernmental side, in the lasting dichotomy in the process of European integration mentioned above, as it has a crucial ground in EU governance. The nature and structure of the Council of the EU can best be illustrative at this respect. The Council of the EU representing the member states works at four levels, namely at the levels of the European Council, ministerial level, Committee of Permanent Representatives (COREPER), committees and working groups. This structure infers a hierarchy of different levels of representation of the member states.

The Council of the EU works in patterns of compromise and consensus, problem solving and negotiation, and mutual accommodation in seek of consensus. ${ }^{28}$ Thus, there is detailed negotiation and bargaining in the Council. Although it is closed to interest groups and non-state actors coming from different levels unlike the Commission, it works in close cooperation with the Commission in the working pattern mentioned above, which sets up an important ground for EU governance. In order to end up with common decisions, the methods of coalition-building, bargaining and package deals are put into practice in the Council of the EU. Thus, in this 


\section{EU Governance}

intergovernmental body of the EU, a process of close cooperation and socialization takes place rather than confrontation, problem-solving and struggle. This constitutes important aspect of EU governance and a subject of analysis for it.

The Council is the most powerful institution in EU decision making. However, it has been argued that neither the Council of the EU nor the Treaties give national governments full control over EU decision-making. ${ }^{29}$ In this sense, it should not be forgotten that the decision-making of the Council exists alongside a directly elected Parliament that has a veto on legislation relating to a third of all treaty provisions. The power of the Parliament in the European political process has grown by leaps and bounds over the past years, and collective national control of decision making has declined as a result..$^{30}$ The Treaties act as a vehicle for national government control. While it is true that national governments have a formal monopoly in making Treaties, it is not all clear that treaty making, or the process of European integration in general, has strengthened national governments against parliaments, regional governments, or public pressures. ${ }^{31}$

It has been suggested that the control of the member states over EU policies and institutions is highly imperfect and that the member states no longer monopolize EU decision-making, partly due to the growing power of the European Parliament in EU policy-making. ${ }^{32}$ In this respect, the Parliament and the evolution in the power of the Parliament is to be taken into account in the discussion of the institutional structure of the EU concerning EU governance.

\section{The European Parliament as the Co-legislator with the Council of the EU}

The European Parliament (EP) has been called one of the most important supranational institutions of the EU in that it has 'established itself' during the European integration process. This phrase is really worth mentioning once the gradual evolution of the legislative powers of the EP is considered. Initially, the legislative power of the EP was only limited to the consultation procedure enacted with the Rome Treaty ${ }^{33}$. In this first phase, it is seen that through taking into account the opinion of the Parliament, the EP somehow intervened in the legislative processes, which was beforehand executed only by the Council of Ministers and the Commission. ${ }^{34}$

The SEA can be seen as a turning point not only in the European integration process but also in the historical evolution of the legislative powers of the Parliament. With the SEA, the legislative power of the Parliament was strengthened through the co-operation procedure ${ }^{35}$. With the Maastricht Treaty, a new step was taken on the evolution of strengthening the legislative power of the EU in that with the co-decision procedure ${ }^{36}$ put into effect, the Parliament has become the co-legislator over much of EU policy. In other words, with this procedure, the Parliament shares decision-making power with the Council of Ministers; it has taken the position of being the common decision-maker with the Council. ${ }^{37}$ Although in 1992, the fields in which the co-decision procedure was applicable were very limited and deficient, with the forthcoming Treaty revisions, after the Amsterdam was signed, the scope of the co-decision procedure was broadened, which increased the participation of the EP in the legislative process of the EU. The use of co-decision was broadened at the Nice Summit until it has become the 'ordinary decision making procedure', covering 90 percent of the fields in the decision making procedure in the Lisbon Treaty ${ }^{38}$.

Another important development for the evolution of the legislative powers of the EP that was put into practice was the assent procedure (avis) ${ }^{39}$. This development is considered as a considerable development for the growth of the power of the EP in that the Parliament depending on the report of the concerned committee decides to accept or reject on accounts of simple majority. ${ }^{40}$ With this procedure, in the areas of the accession of new member states, and the establishment and amendments of association relations, a proposal must be approved both by the Council of Ministers and the Parliament in order to be enacted. ${ }^{41}$

The EP is better explained in terms of the response of national governments to domestic pressures for greater democratic accountability in the EU. The emergence of the EP as a powerful 


\section{N. Nevra Esentürk}

European player has altered the institutional balance in the European Union. ${ }^{42}$ The authoritative competences of the EP are more narrowly circumscribed than those of the Council, but the EP is nonetheless a weighty player. As a result, national governments cannot impose their collective will in many areas of policy making. In this perspective, the gradual growth in the power of the EP during the evolution of its history outlined above, means growth in the power of the citizens represented in the Parliament, which overall contributes to the democratization of the Union. In this

| 8 respect, the evolution of the development of the EP sheds light on the process of democratization in the EU as well as enhances the legitimacy of the EU, for the EP which has been directly elected since 1979, has staged a process of development not only via its voting pattern, working style and organization structure but also through its openness and transparency towards the public. ${ }^{43}$ These are very big steps in terms of overcoming the 'democratic deficit' in the EU.

At this point, the scrutiny role of the EP over the executive is to be mentioned, as the EP has gained this role depending on the changes in the Treaty revisions addressing the democratic deficit of the EU. There are two main aspects of the ability of the EP to exercise control over the Commission. The first one is in its power over the appointment of the College of Commissioners, and the second is in its power to dismiss Commissioners if it disapproves of their conduct. ${ }^{44}$ Although the EP does not originally have the power on the appointment of a new Commission, with the Treaty amendments, the Parliament incrementally extended its powers concerning this issue, and with the Amsterdam Treaty, it was given a formal right in the approval of their nominee for President of the Commission. ${ }^{45}$ Having gained the right to approve the appointments of the President, and separately of the other Commissioners as whole, the EP did some procedural adaptations to increase the leverage of the modest extra powers granted in the Maastricht Treaty. ${ }^{46}$ In that regard, the other aspect of parliamentary control over the Commission is in its power to dismiss Commissioners. At this point, the powers of the EP to approve the new Commission President and college of Commissioners took center-stage, which can be seen in Prodi and Barroso Commissions. Concerning the democratic scrutiny function of the Parliament, the EP also has the right of inquiry through addressing written and oral questions to the members of the Commission and the Council and set up committees of inquiry. ${ }^{47}$ The Parliament within the framework of the abovementioned scrutiny function over the executive, acts a watchdog over the institutions of the EU.

The growing power of the EP has an important place for the functioning of EU governance, as EU decision-making has come under greater public scrutiny. Since the SEA, the technocratic European integration process has changed. As the reach of European policy making broadened, and as the stakes in most issue areas grew, domestic groups were drawn directly into the European arena. ${ }^{48}$ Such mobilization has created new linkages between supranational institutions and subnational groups. EU decision making is no longer insulated from the kind of political competition that has characterized democratic politics in the member states. ${ }^{49}$

In line with the main supranational institutions, and their abovementioned structure, it can be argued that EC's institutional set-up is characterized by a multi-level structure, a combination of supranational and intergovernmental elements, and a strong role for the judiciary. ${ }^{50}$ Thus, the Commission operates in a system of multi-level governance involving competition and interdependence among it and the European Council, the Council of Ministers, and the EP, all of which share authority in the intricate game of policy initiation. ${ }^{51}$ During the policy cycle, the EC's actors are largely restricted to agenda-setting and policy formulation and decision-taking, whereas implementation is organized by the member states. Formal powers are overshadowed by multilayered negotiations and consultations. Owing to these characteristics, it is almost inevitable that the European Community's mode of governance will be of the network type, which differs from ideal type pluralism, statism and corporatism. ${ }^{52}$ The actors have different interests and they are 'mutually dependent, but at the same time autonomous'.

Within the framework of the dichotomy between state centric and multi-level governance, upon the evaluation of the key actors mentioned above, it can be seen that there is a diffusion of control even in this multi-level, heterogeneous composition and complex institutional set up of the EU. In addition to the mobilization of subnational interests beyond the reach of national 


\section{EU Governance}

governments directly in the European arena, interest groups have mobilized intensively in the European arena. ${ }^{53}$ In broad perspective, although the power of the interest groups is difficult to pinpoint, it is clear that among the supranational institutions of the EU, the Commission is the most open platform in that regard, especially with the passage of the SEA that precipitated a sharp increase in interest group representation in Europe. In that respect, most groups target their lobbying activity at the European Commission, then the EP, as these are perceived to be more accessible than the secretive Council of the EU. Akin to the evolution of the development of the Parliament in terms of its growing power over the last decade, a dramatic change has been prompted in its relationship with the lobbyists. This shows that the EP has adopted a more open and practical approach for regulating the relationship between the institutions and outside interests, the practical side of which is going to be discussed below.

\section{The Court of Justice of the European Union as the Interpreter of European Union Law}

The Court of Justice of the European Union is the supreme judicial institution of the EU, undertaking the main task of examining the legality of Community measures and ensuring the uniform interpretation and application of the EU law. ${ }^{54}$ The judgments of the Court have the absolute power of sanction and are binding for all Union citizens and the member states. ${ }^{55}$ Concerning the structure of the Court of Justice, the Court which meets in Luxembourg comprises twenty-seven judges and eight advocates general, who are appointed by common accord of the governments of the member states and hold office for a renewable term of six years. ${ }^{56}$

Upon this structural ground, the Court of Justice has significant functions in that it is responsible for the interpretation and implementation of EU law and acts as final arbiter in disputes arising from EU law. ${ }^{57}$ In that regard, it has wide-ranging powers to hear various types of action and to give preliminary rulings $s^{58}$ and direct actions. The types of action the Court may hear are namely proceedings for failure to fulfill an obligation; proceedings for annulment of EC legislation; proceedings for failure of an EU institution to act; actions for damages; and appeals against judgments of the Court of First Instance ${ }^{59} .{ }^{60}$

The Court has had important contribution to the development of the EU in terms of "constitutionalization' ${ }^{61}$ of EU law and policy development. Concerning the former issue, through its case-law, the Court identified the principles of direct effect (i.e. individuals gaining rights from the implementation of EU law), direct effect of Community law in the member states, the supremacy of Community law over national law and the liability of a member state to individuals for damage caused to them by an infringement of Community law by that State. ${ }^{62}$ These principles which had profound impacts on the nature of EC law were the results of the cases such as Van Gend en Loos (1963), Costa v. Enel (1964), Van Duyn v. Home Office (1974), Factortame (1990), Francovich v. Italy (1991). Since 1991, European citizens have therefore been able to bring an action for damages against a State which infringes a Community rule. The subsequent rulings confirmed these principles of EU law.

In addition to the contribution of the Court to the legal system of the Union, the Court has made substantial contribution to the integration process through its role in developing particular policy sectors. In that regard, concerning the policy-making in the EU, the Court acts as an activist actor in a supranational legal order. ${ }^{63}$ The development of the Court's case-law illustrates its contribution to creating a legal environment for European citizens by protecting the rights which Community legislation confers on them in various areas of their daily life. The progressive rulings of the Court of Justice have been seen in matters of free movement of goods, free movement of persons, freedom to provide services, equal treatment and social rights. Some of the significant cases, as samples for the Court's judgements in the abovementioned areas are Cassis de Dijon judgment in 1979 on the principle of free movement of goods, Kraus judgment in 1993 on the principle of free movement of persons, Cowan judgment of 1989 on the principle of freedom to 


\section{N. Nevra Esentürk}

provide services, Defrenne judgment of 1976 on equal pay for men and women for equal work, Brown judgment of 1998 on equal treatment for men and women.

Considering the active contribution of the Court of Justice to the European integration process in the abovementioned two respects, the relations of the Court with the European Commission is important to be noted. The Court has been active in transforming the legal order in a supranational direction in cooperation with the Commission. ${ }^{64}$ Through this activist stance, the Court has laid the legal foundation for an integrated European polity. ${ }^{65}$ In particular, the development of the Community's legal system, and especially the doctrines of direct effect and supremacy, also increased the capacity of the Court to influence substantive policy-making in Europe. The EP has benefited from the Court's jurisprudence in supranational direction in that in series of judgments the Court has interpreted the powers of the EP in an expansive manner, based on the principle of 'institutional balance' ${ }^{66}$ Some important cases in this regard can be illustrated as Isoglucose Case (1979), Parti Ecologiste 'Les Verts' v. Parliament (1986), the Comitology Case (1988), the Chernobyl Case (1990). Though this way, the ECJ has helped for the progress of EU governance. In all these respects, the ECJ acts as an active actor in the European integration process and as an authoritative interpreter of both the Treaties and the secondary legislation put in place by the member states.

\section{Interest Groups as Non-State Lobbyists}

In the European integration process, interest representation at the European level is conditioned by its fragmentation and the unique multi-level character of EU power, decision-making and policy processes. ${ }^{67}$ The above mentioned institutional set up of the EU involves the engagement of subnational, member state and supranational tiers of authority, and the complex interplay between them creates multiple arenas, venues and points of access. As the shifting of EU decision-making arenas, powers, and procedures occurs depending on the issue at stake and the Treaty specifications, there has been an incremental tendency towards Community decision-making rules over time in the European integration process, which has considerably influenced the character of EU interest representation by focusing it at the supranational level. ${ }^{68}$

Considering policy-making in the EU, competence is contested among the four EU institutions. This has enhanced the mobilization of interest groups intensively in the European arena. Taking into account the basic characteristics and tasks of the Commission, it may be asserted that the Commission, the foremost institution which takes the input seriously among these four main EU institutions, is particularly supportive of interest group representation in Europe. Due to the difficulty in accessing the Council, interest groups tend to concentrate their efforts at the national level or in individual member states' permanent representations in Brussels. As discussed above, the vast bulk of lobbying is directed towards the Commission and the Parliament. The Commission's role in drafting legislation, together with its interdependencies with outside interests due to the specialized knowledge of organized groups, makes it the foremost channel for interest representation at the European level. ${ }^{69}$ The Commission believes that the involvement of non-state actors in the policy-making process is fundamental to the development of its policies. This dialogue has proved valuable to both the Commission and to the interests of outside parties.

Emphasizing the increased mobilization of interest groups in EU decision-making, it is vital to mention their role in this process with regard to EU governance. The presence and role of organized interests in EU policy and politics have attested a transformation with the expansion of the membership of the Union and the successive Treaty changes and enlargement. The degree of power, status and influence of the many organized interests outside the formal institutions are still unclear; however, since the 1980s, there has been a dramatic increase in their number and influence as a manifestation of the EU's expanding remit. ${ }^{70}$

For these reasons, there has been a rapid growth in interest group activity at the European level. Interest groups may be classified according to the main interests they represent and the 


\section{EU Governance}

membership composition of different groups. In this perspective, there are various forms of interest groups ranging in scope from those organizing 'horizontal' interests across a particular constituency (such as confederations of producer interests or citizens) into sectoral type interests, to specialist issue organizations. ${ }^{71}$ The large groups representing 'horizontal' or cross-sectoral interests include the Union of Industrial and Employers' Confederations of Europe based around national federations, the European Association of Craft, Small and Medium-Sized Enterprises the lead organization for small and medium sized enterprises (SMEs), the European Centre of Employers and Enterprises providing Public Services representing public-sector employers and the European Trade Union Confederation the principal organization representing worker interests. ${ }^{72}$ In addition, there are also private interests, public interest bodies, governmental actors, public-private interests and autonomous agencies among these interest groups. The European Round Table of Industrialists (ERT) works for business interest representation. It describes the role of private interests in helping the Commission to develop policy drafts, or policy solutions, in low politics fields, in conditions favourable to access and influence by non-state actors. ${ }^{73}$

There is a competitive and complex interest representation. Whatever their type, interest groups seek to shape EU decision-making through lobbying. All lobbyists in Brussels try to intervene and influence the formal institutional decision-making structure of the EU. However, there are also less formal ways of doing this which is generally fulfilled particularly by organized interests, as they are important sources of information and advice for EU policy makers and add depth to a legislative process that in formal treaty terms only involves the Commission, the Parliament, the Council and the Economic and Social Committee (ESC) and the Committee of the Regions. ${ }^{74}$ Interest groups are categorized in terms of the forms of interest representation that coexist in the EU. Within the framework of these forms of representation, the full institutionalization of interest representation of is carried out through the ESC.$^{75}$ However, the ESC has never found itself a lasting riche in European decision-making and is still deemed an insufficient form of representation for the interest groups concerned.

\section{Voluntary and Intergovernmental Aspects of EU Governance}

Based on the abovementioned dynamics in the institutional framework of the EU, the voluntary and intergovernmental aspects of EU governance such as multi-level governance, policy networks, and the recent Open Method of Coordination reflect the practical means and ways in the use of it in the decision-making and policy-making process of the EU.

Together with the impacts of the international developments in the decade or more after 1990, namely globalization, devolution in Europe, and economic liberalization, new and different forms of governance, in which power was increasingly shared horizontally have appeared. ${ }^{76}$ Moreover, concerning internal dynamics, it is claimed that the very fragility of the EC's democratic legitimacy has important implications which in combination with the EC's institutional properties, contributed to the emergence of a network mode of governance. ${ }^{77}$ The growing interest in network forms of governance reflects how modern society, culture and economy are all increasingly products of relations involving mutuality and interdependence, as opposed to hierarchy and independence. $^{78}$

\section{Multi-level Governance}

Multi-level governance ( $M L G$ ) is a significant means for the implementation of EU governance, to be discussed in terms of its definition, logic, and characteristics. In the first place, it should be noted that the MLG approach is part of a new wave of thinking about the EU as a political system. According to this thinking, the EU is best understood as a new form of complex, multilevel system 


\section{N. Nevra Esentürk}

in which decision-making and implementation authority is shared across multiple 'tiers': subnational, national, transnational, and supranational. ${ }^{79}$

The first traces of the MLG approach goes back to 1992 when it was first introduced by Gary Marks to capture the developments in EU structural policy that made structural funds subject to administration through partnerships between local, national and supranational actors. However, with the growing increase in this trend of the governance since the 1990s expectations for its application to different policy areas such as environmental and social policy have arisen. For the implementation of the multiple-venued policy-making, and policy coordination type new governance modes have been put into practice, such as policy networks and Open Method of Coordination (OMC) as tools or "establishing regulation by persuasion and by negotiation' 80 in the form of soft law within the framework of the complex and constantly changing policy-making procedure of the EU. As governance involves setting goals and making decisions for an entire collectivity, OMC aims to spread best practices and achieve greater convergence towards the main EU goals.$^{81}$ Moreover, with the growth of multi-level networks, the EU system also produces what some call 'soft law', which includes action programmes, declarations by the European Council, guidelines, communications. ${ }^{82}$

Based on the assumption that the sovereignty of the European state has been eroded from several directions both externally through deregulation of trade and financial markets and internally by collective decision-making within the EU, dispersing the decision-making authority across different spatial locations, the MLG approach describes the characteristics of EU governance with the following terms; namely 'multiple actors', 'differentiation', 'technocracy', non-hierarchical decision-making', and 'informal relations' ${ }^{83}$

Within the framework of governance, referring the patterns of horizontally dispersed power, taking various formal or informal institutional shapes, the above mentioned terms can be explained with the involvement of a variety of public and private actors at the national, supranational, and international level for policy-making and implementation with functional differentiation according to distinct policy sectors. This type of governance displays a political, and technocratic in nature, without any kind of classical hierarchical decision-making, within the framework of predominantly informal interactions between policy actors. ${ }^{84}$

At this point, one of the clear-cut values of consensus turned up to emerge in the following aspects. Having the above mentioned characteristics of MLG, as policy making in a multi-level system of governance includes the particular practice of coordinating the activities of different levels of governance; local, regional, national, supranational and transnational, it requires direct negotiation and bargaining between actors situated at different levels of decision-making. ${ }^{85}$ Thus, negotiation and coordination as well as competition have emerged as vital for MLG approaches to reach consensus for policy-making in different policy areas. In this sense, several kinds of administrative arrangements are said to typify EU decision-making, including 'policy networks', 'expert committees', 'regulatory agencies', the 'open method of coordination' and 'directly deliberative polyarchy'. Among the most frequently stressed arrangements is governance through so-called 'policy networks' ${ }^{86}$ The concept developed during the 1990s and was characterized by predominantly informal interactions between public and private actors who cooperate to solve problems of collective action. In the EU context, an often-cited reason for the spread of policy networks is the relative scarcity of EU resources. Due to its limited budget and personnel, the only way for the Union to deal with the burden of decision-making and implementation is to encourage the formation of elite policy networks that facilitate exchange of information and ideas and build consensus through informal exchange and backroom bargaining. ${ }^{87}$

Considering the policy-making in MLG system of governance, a typical policy network may involve semi-autonomous parliamentary committees and bureaucratic agencies inhabited by experts as well as private actors with special expertise and competence in a policy area ${ }^{88}$ The formation of networks is significant in terms of facilitating exchange of information and ideas, and building consensus through informal exchange and backroom bargaining. 


\section{EU Governance}

It is important to highlight that the MLG model does not reject the view that state executives and state arenas are important, and consider them as the most important pieces of the European puzzle; but, it is asserted that the state no longer monopolizes European level policy-making, which put a different polity into focus. According to the MLG model, decision-making competencies are shared by actors in cooperation as well as competition at different levels rather than monopolized by state executives. That is to say, supranational institutions (EC, ECJ, EP) have independent influence in policy making that cannot be derived from their role as agents of state executives. State executives may play an important role but, according to the MLG model, one must also analyze the independent role of European level actors to explain European policy-making.

Although MLG has contributed to the European integration process in enhancing the implementation of EU governance for the internal functioning of the EU, it has some weaknesses stemming from the problem of administrative feasibility. A governance system which was arranged across multiple jurisdictions is liable to high transaction costs of coordinating multiple jurisdictions ${ }^{89}$ The focus by MLG scholars on maximum decentralization and flexibility appears to throw up a conundrum in the process.

In this context, MLG is criticized on the grounds that it suffers from a lack of theoretical focus and explanatory power. It rather offers a descriptive rather than a theoretical approach to the study of European integration. Terms such as 'multi-tiered', 'multi-level' and 'fragmented' describe the complexity of the EU political system but do not provide a framework for explaining how this system functions and why. ${ }^{90}$ It fails to supply an operational framework for policy analysis. It provides no clear predictions about the outcomes of the EU governing process. MLG studies are introspective. ${ }^{91}$ Although MLG is a descriptive approach not offering a theory of integration together with the weaknesses mentioned above, it is useful as it depicts complexity as the principle feature of the EU political system and invites us to draw on a combination of other theories to explain European policy outcomes, with a clear normative commitment to decentralized policymaking.

\section{Policy Networks}

Common to more specific definitions of governance is the view that policy-making is increasingly characterized by the wide participation of public, private and voluntary actors. In the context of the $\mathrm{EU}$, as mentioned above, the multi-level governance framework brings together the increased 'horizontal' mix of actors with increased 'vertical' interactions between actors organized at different territorial levels, supranational, national and sub-national. ${ }^{92}$ In that respect, "policy networks', which are characterized by predominantly informal interactions between public and private actors who cooperate to solve problems of collective action appears as the most stressed administrative arrangements in the structural domain of governance and the most characteristic feature of EU governance. ${ }^{93}$

Within the framework of multi-level governance, policy networks have become both more common in the policy literature and progressively more ambitious. The core hypothesis is based on the transformation towards a network mode of governance at the level of the European Union. Depending on the perception of governance as the 'sharing of tasks and responsibilities between private and public actors' ${ }^{94}$ and 'heterogeneous composition and complex institutional set-up' ${ }^{95}$, regimes around which actors, expectations can converge are needed, in which subsidiarity, reciprocity and cohesion are given the utmost importance in all policy areas. It is contended that these structures shape the terms of European political discourse. Thus, we have seen the emergence of policy networks created by the Commission bureaucrats, national bureaucrats, a variety of different actors and experts and representatives of interest groups.

From this perspective, the multi-level policy-making procedure is different from the states' classical form of hierarchical decision-making. In other words, this approach is a top-down process realized with the involvement of multiple actors and negotiation process in policy networks, actors 


\section{N. Nevra Esentürk}

with very different strengths, level of power and instruments. In this modern governance in the EU, there has been a shift towards a 'sharing of tasks and responsibilities; towards doing things together instead of doing them alone ${ }^{96}$ to engage in collective action.

Based on the assumptions that policy network analysis is non-hierarchical governance involving mutuality and interdependence between public and non-public actors, as well as between different kinds of public actor, governments nevertheless remain ultimately responsible for governance. ${ }^{97}$ But, before policies are 'set' by elected political actors, policy choices are shaped and refined in bargaining between a diverse range of actors, including some who are nongovernmental, all of whom have an interest in what policy is chosen.

EU policy networks are important supporters of multi-level governance, but it has also been criticized in the following ways. In the first sense, 'policy network' does not constitute a model or theory. The fluid, uncertain, overpopulated policy-making in Brussels with a diverse collection of interests does not comply with the existence of stable networks which is necessary in the policy network approach. ${ }^{98}$ Moreover, policy network analysis lacks a theory of 'power' which weakens its functional position. Thus, the literature on policy networks often appears vague with insufficient debates about terminology. Although the policy network approach has been criticized mainly on the points mentioned above, EU policy network analysis has contributed to explaining the European integration process in terms of emphasizing the Union's inescapable diversity and complexity.

Nonetheless, there are still question marks for the future development of policy network analysis, depending on the extent of its success in performing the functions of effectively describing, explaining, and even predicting outcomes of new EU policy methods and modes. ${ }^{99}$ Although there is a complex picture of governance at European level with the widely divergent member-state modes of governance and area specific variations, most EU policy areas are marked by the preponderance of network governance. ${ }^{100}$ Thus, it is widely regarded that in order to bridge the heterogeneity of EU member states and socio-economic actors as well as to compensate for the fragile democratic accountability, the elements of functional representation need to be introduced through policy networks. ${ }^{101}$ In conclusion, despite the question marks for the future of policy networks, the significant impact of the policy network on the process of the European integration should not be underestimated in that it provides the means of explaining what European integration has wrought in terms of governance, which has made the EU more eclectic as a polity as its policy competence has expanded, and more polycentric.

\section{Open Method of Coordination}

The Open Method of Coordination (OMC) process was launched at the Luxembourg summit in 1996 and developed in the so-called European Employment Strategy (EES). The Lisbon summit conclusions of 23-24 March 2000, which set out to charter the Union's trajectory for the next decade, endorsed the OMC as an alternative method of supranational governance to guide various policies on employment, the social exclusion, including such issues as poverty, long-term unemployment, social protection, and pensions. ${ }^{102}$

It is declared in the conclusion of the Lisbon European Council that through this alternative new mode of policy-making, "Europe was to become the most competitive, dynamic, knowledge based economy in the world, capable of sustainable economic development, with more and better jobs and social cohesion." 103 Technically, this method is to be brought about through such means as benchmarking, target setting and peer review which were developed in the Luxembourg, Cardiff and Cologne processes. ${ }^{104}$ The OMC thus elevates the governance regime developed by the EES to a general method of cooperation that may be adopted in other areas, but does not add anything new to it.

Concerning the reasons behind the introduction of the $\mathrm{OMC}$, it is important to mention the context in which the OMC was initiated. In the context where the OMC was introduced, it was 


\section{EU Governance}

widely perceived that any contradictions between the economic and social policies are to be overcome through the development of productive social policy, and that the problems of rising unemployment, and the inability of the member states to deal with this problem put the issue at the top of the Lisbon Agenda. The Lisbon Agenda specified the challenges that the EU has faced are specified as 'politically sensitive areas' (pensions, social inclusion and employment) where the use of the existing Union method would be impossible. ${ }^{105}$ Thus, the context reveals that the areas where national interests are very strong and in which there is no Treaty mandate for European level action, and where there is a huge diversity among the member states emerged as significant challenges for the future of the European integration phenomenon. In other words, since EU policy-making moves into politically sensitive areas where the use of the Union method is problematic due to difficulties in achieving policy convergence, new methods of governance are required to be developed where coordinated action is possible. ${ }^{106}$

The basic reason behind the emergence of the OMC was that there was an urgent need to consider national policies as a 'common concern', and that a certain amount of policy coordination and convergence was required to be attained at the European level. ${ }^{107}$ In that regard, the need to achieve a certain policy convergence has led to the development of particular procedures for establishing common objectives and achieving member state compliance, including the setting of common objectives and guidelines at the European level which the member states are expected to implement in their national policies. ${ }^{108}$ Thus, in the Lisbon Summit, the key elements of the OMC are defined as 'fixing guidelines, translating the European guidelines into national and regional policy, setting specific and adapting measures, establishing quantitative and qualitative indicators and benchmarks as a means of comparing best practice, periodic monitoring, evaluation and peer review, 109 .

In the process of the development of the OMC, the Lisbon Summit is the point in which the method was named, linking it to the new agenda for socio-economic development. Based on the abovementioned key elements, the OMC emerged as a decentralized mode of decision-making which complements the more traditional Union method in which the Commission does not function as the 'motor' of integration. Rather, the member states form their own way of policy coordination and convergence. They accomplish this by means of placing objectives at a central level from which common guidelines are prepared to be translated into national policy, measuring through certain indicators, decentralized implementation and systemic monitoring in the form of periodic reporting and evaluation of progress that is put into practice through 'best practice' exercises and peer review. ${ }^{110}$ Upon this procedures and structure, OMC can be considered as an alternative method of supranational governance to be brought through such means as collective recommendations, review and monitoring, and benchmarking. ${ }^{111}$

The OMC which is originated and structured on these grounds represents the emergence of 'new forms of governance'. ${ }^{112}$ The OMC using the abovementioned means provides real flexibility and marks a further maturation of the integration process. This new approach to EU governance suggests a non-hierarchical, de-centred and dynamic process, supporting the principle of subsidiarity and suggesting an alternative to the Treaty rules on enhanced cooperation and addresses some of the legitimacy issues inherent in the EU. ${ }^{113}$ It is a method in which "the Union, the member states, the regional and local levels, as well as the social partners and civil society, will be actively involved, using variable forms of partnership" ${ }^{114}$.

The OMC which has been utilized as a 'soft' strategy to achieve greater integration in policy fields emerged as an enhancing method for multi-level governance, as the explicit intention of the method is the involvement of a wide range of actors that denote a wider understanding of democracy as a participatory mechanism. ${ }^{115}$ Thus, the participation of social, sub-national and local actors becomes essential for a successful definition and implementation of national plans, as seen in the case of employment. In a world of economic globalization, in order to fulfill the 2020 Strategy and achieve a stable framework of governance, the OMC emerges as an important tool to be utilized to enhance EU governance. 


\section{N. Nevra Esentürk}

\section{EU Governance in Analytical Perspective}

Throughout the European integration process, it is clear that there has always been a dichotomy between supranationalism and intergovernmentalism. As Pollack states, in the place of the traditional neo-functionalist/ intergovernmentalist debate, the 1990s witnessed the emergence of a new dichotomy in EU studies, pitting rationalist scholars in favour of formal models against constructivists focusing on the relevance and importance of soft law, construction of meanings, values, and identities. ${ }^{116}$ In that regard, depending on the internal dynamics of the EU concerning economic integration and enlargement as well as the external ones such as globalization and the adoption of neoliberal policies, necessitating interaction at different levels and cooperation among various actors internally and interdependence across boundaries externally.

This has prompted a general move towards governance in the EU since the 1990s. Then, coupled with the formation of the multi-level, complex, institutional set up of the EC characterized by negotiations among independent actors and institutions, and respecting member state autonomy, EU governance, which is based on the internal functioning of the EU has evoked interest in a general orientation of decision-making that is compatible with Union-wide policies. ${ }^{117}$ This system requires a non-hierarchical organization in which actors at both national and subnational levels, intervene in the process of policy-making, resulting in interaction between different levels of authority. ${ }^{118}$

The internal dynamics of the EU have provoked the scrutiny put for the legitimacy and representative power of the EU and its institutions. In that respect, EU governance constitutes one of the key issues in the integration process of the EU. It has been considered as a remedy for the democratic legitimacy crisis as well as an efficient way of functioning for the enlargement of the Union. With enlargement, there would be much more variety that would necessitate more coordination. Network mechanisms at this point can be used as an efficient coordination tool.

With the Lisbon Treaty, there increased the power of the EP in the legislative process. With the co-decision procedure, as the normal legislative procedure, the EP has become the co-legislator with the Council of the EU. In addition, the Union having a single legal personality intends to increase the democratic legitimacy of the EU on the one hand and the efficient functioning of the EU on the other. The steps to be taken towards political integration is very much related to the extension of the areas in which competence has been delegated to EU institutions and the content of the decision-making mechanisms in those areas.

The crucial question to be asked in the Lisbon Treaty is to what extent and how the EU can respond the EU's objectives to be more democratic and efficient. If there is good governance, is it possible to cover the deficit in the implementation and democratic legitimacy. With enlargement, there would be much more variety that would absolutely necessitate more coordination. Network mechanisms at this point can be used as an efficient coordination tool.

The OMC is preferred by the member states issues in voluntary and intergovernmental terms. OMC is open to nongovernmental actors in principle. But in practice, it is seen that the involvement of non-governmental actors are not at the desired level. Negotiation process is done mostly among governments and private actors do not intervene in setting the common objectives and implementation of them at national level. ${ }^{119}$

EU governance is indispensable for the EU considering the following issues. In the first place, the workload of the Commission has increased with an enlarged and integrated Europe. It was decided by the Council of Ministers not to extend the size of the Commission. Thus, it is necessary to gather the resources and do much more with the same resources, which requires intense cooperation as well as competition by governance. The second issue is related with the challenges that the EU faces, one of which is the legitimacy crisis. The EU institutions, especially the EP and the Commission have been in quest for ways to come closer to its citizens with its multi-level structure of governance. Moreover, the fragmented character of the Union policies have had a deep impact on the transparency and consistency of the EU. Thus, there may occur some inconsistencies among the policies and the policy objectives and their results. Many structures set up by the Council 


\section{EU Governance}

is far away from strong political leadership and long-term consistent strategies. The Commission is also struggling with inter-coordination problems in its structure.

On the other way round, the EU is faced with lots of overlapping difficulties and challenges. The EU has had structural weaknesses with regard to average growth, employment rates and demographic ageing. The EU must strengthen the ties between its national economies in the face of global problems and develop its concerted action. The EU must position itself clearly in the global competition for investments, production locations and leading edge technologies. At the same time, it needs to take lessons from the financial and economic crisis, as well as climate and recourse scarcity in order to focus on the challenges of the coming decade. All of these issues necessitates a more comprehensive coordination among the member states at vertical and horizontal levels. The areas of cooperation can be enlarged from international terrorism to foreign affairs, drug trafficking to migration and environmental protection policies. All in all, governance has become a fact that none of the Union institutions can disregard.

EU's democratic legitimacy quest can be seen in the transparency principle and the move to make the Union much more closer to its citizens. The basic values on which the EU is built on indispensably have found its reflection on the local and regional administrations' role in EU governance. However, EU governance is vague in terms of the subsidiarity principle. It has been interpreted differently by different political actors. On the other way round, the supranational centralization and hierarchy has created a mistrust on the EU institutions and decision-making structures from the perspective of citizens. The EU overall not having a demos is another important problem with regards to democratic deficit.

\section{Conclusion}

Although the Lisbon Treaty has reflected a simple framework for the complex decision-making process regarding EU governance, it is still difficult to have clear-cut competences between member states and EU institutions, which has been limited with struggle between cooperation and competition at vertical and horizontal levels under the shadow of supranational hierarchy. Governance in its nature is vague, run in a non-hierarchical way in which not only formal institutions but also non-formal actors engage in. It is composed of both public and private actors in networks. This complex picture is complemented with a multi-level structure ranging from supranational to local levels. It has been limited with struggle between cooperation and competition at vertical and horizontal levels under the shadow of supranational hierarchy that has created mistrust on the EU institutions and decision-making structures from the perspective of citizens.

However, in several policy areas, EU policies are set up and implemented via methods combining legal and non-legal, supranational and national as well as public and private. In that respect, it is figured out that the EU has internalized different aspects of governance. That's why, governance can be regarded as a combination of approaches emphasizing common themes rather than a single approach in relation to European integration. It also signifies an ambitious project in terms of objectives, seen as a tool that would increase the competitiveness of the EU and bring the citizens closer to the EU institutions. How the EU would react to the current limits of EU governance would be decisive to have either a more liberal or competitive Europe or a democratic and social one.

\section{Notes}

\footnotetext{
1 Bache, I. and George, S. (2006), Politics in the European Union, Oxford: Oxford University Press.

2 Hooghe, L. and Marks, G. (2003), "Multi-level Goverance in the European Union”, in Nelsen, B. F. and Stubb, A. (eds.), The European Union: Readings on the Theory and Practice of European Integration, New York: Palgrave Macmillan, p. 285.

3 Heriter, A. (2002), “New Modes of Governance in Europe: Policy Making without Legislating?”, Political Science Series, Vienna: Institute for Advanced Studies.
} 
4 Kooiman, J. (ed.) (1993), Modern Governance: New Government-Society Interactions, London: Sage Publications., p. 4.

5 Hooghe, L. and Marks, G. (2003), "Multi-level Governance in the European Union”, in Nelsen, B. F. and Stubb, A. (eds.), The European Union: readings on the Theory and Practice of European Integration, New York: Palgrave Macmillan, p. 282.

6 Eising, R. and Kohler-Koch, B. (1999), “Governance in the European Union: A Comparative Assessment”, in Kohler-Koch, B. and Eising, R. (eds.), The Transformation of Governance in the European Union, London and New York: Routledge, p. 269.

7 Committee of Independent Experts (1999), First Report regarding Allegations of Fraud, Mismanagement and Nepotism in the European Commission, Luxembourg: Official Publications of the European Communities.

8 European Commission (2001), White Paper on European Governance, COM (2001) 428 Final, 27 July 2001, Luxembourg: Official Official Publications of the European Communities.

9 Hooghe, L. and Marks, G. (2003), "Multi-level Governance in the European Union”, in Nelsen, B. F. and Stubb, A. (eds.), The European Union: Readings on the Theory and Practice of European Integration, New York: Palgrave Macmillan, p. 285.

10 Hix, S. (1998), “The Study of the European Union II: The 'New Governance' Agenda and Its Rival”, Journal of European Public Policy, 5 (1), p. 342.

11 Ibid, p. 343.

12 Wiener, A. and Diez, T. (2004), European Integration Theory, Oxford: Oxford University Press, p. 102.

13 Ibid.

14 Ibid.

15 Hooghe, L. and Marks, G. (2003), "Multi-level Governance in the European Union”, in Nelsen, B. F. and Stubb, A. (eds.), The European Union: Readings on the Theory and Practice of European Integration, New York: Palgrave Macmillan, p. 295.

16 Ibid, p. 296.

17 Ibid.

18 Bache, I. and George, S. (2006), Politics in the European Union, Oxford: Oxford University Press, p. 263.

19 Ibid, p. 270.

20 Ibid, p. 271.

21 Hix, S. (2005), The Political System of the European Union, Basingstoke: Palgrave, p. 52.

22 See OJ L 197/33, 18.7.1987.

23 See OJ L 184/23, 17.7.1999.

24 See OJ L 200/11, 22.7.2006.

25 Ibid.

26 Hooghe, L. and Marks, G. (2003), "Multi-level Governance in the European Union”, in Nelsen, B. F. and Stubb, A. (eds.), The European Union: Readings on the Theory and Practice of European Integration, New York: Palgrave Macmillan, pp. 295.

27 Ibid, p. 290.

28 Bache, I. and George, S. (2006), Politics in the European Union, Oxford: Oxford University Press, p. 279.

29 Ibid, p. 288.

30 Bache, I. and George, S. (2006), Politics in the European Union, Oxford: Oxford University Press, p. 279.

31 Ibid.

32 Hooghe, L. and Marks, G. (2003), "Multi-level Governance in the European Union”, in Nelsen, B. F. and Stubb, A. (eds.), The European Union: Readings on the Theory and Practice of European Integration, New York: Palgrave Macmillan, p. 290.

33 See Article 137 of the Commission of the European Communities (1978), Treaty of Rome, Treaties Establishing the European Communities, Luxembourg: Office for Official Publications of the European Communities.

34 Kabaalioglu, H. (1991), “Avrupa Parlamentosu”, Marmara Üniversitesi Avrupa Araştırmaları Dergisi, 1, p. 247.

35 Bu procedure was enacted under Articles 6 and 7 of the SEA.(OJ L 169, 29.6.1987), for the three-step procedure, see ibid, p. 26.

36 See, European Union (1992), Maastricht Treaty, Agreement on Social Policy Concluded between the Member States of the European Community with the Exception of the United Kingdom of Great Britain and Northern Ireland, http://europa.eu.int/en/record/mt/protocol.html, (retrieved: June 1, 2007, from World Wide Web: URL) 37 Tezcan, E. (2001), Avrupa Birliği Kurumlar Hukuku, İstanbul: Beta Yayınları, p. 30.

38 European Union (2000), Lisbon European Council, Presidency Conclusions, Retrieved: May 4, 2007, from World Wide Web: URL

http://www.consilium.europa.eu/ueDocs/cms_Data/docs/pressData/en/ec/00100-r1.en0.htm

39 Thi procedure was enacted under Articles 8 and 9 of the SEA (OJ L 169, 29.6.1987)

40 Tezcan, E. (2001), Avrupa Birliği Kurumlar Hukuku, İstanbul: Beta Yayınları, p. 38.

41 Yörüng, M. T. (1991), “Avrupa Tek Senediyle Avrupa Parlamentosu'na Tanınan Yetkiler”,MarmaraÜniversitesi Avrupa Araştırmaları Dergisi, 1, p. 306.

42 Hooghe, L. and Marks, G. (2003), "Multi-level Goverance in the European Union”, in Nelsen, B. F. and Stubb, A. (eds.), The European Union: readings on the Theory and Practice of European Integration, New York: Palgrave Macmillan, p. 291.

43 Auel, K. and Benz, A. (2000), “Strength and Weakness of Parliament in EU Multilevel Governance - Accountability in a Compounded Representative Democracy “(paper presented at the IPSA World Congress), 1-5 August 2000, Quebec.

44 Bache, I. and George, S. (2006), Politics in the European Union, Oxford: Oxford University Press, p. 302.

45 Ibid.

46 Ibid.

47 Hooghe, L. and Marks, G. (2003), "Multi-level Goverance in the European Union", in Nelsen, B. F. and Stubb, A. (eds.), The European Union: readings on the Theory and Practice of European Integration, New York: Palgrave Macmillan, p. 297.

48 Ibid, p. 293. 


\section{EU Governance}

49 Ibid, p. 291.

50 Eising, R. and Kohler-Koch, B. (1999), “Governance in the European Union: A Comparative Assessment”, in Kohler-Koch, B. and Eising, R. (eds.), The Transformation of Governance in the European Union, London and New York: Routledge, p. 269.

51 Hooghe, L. and Marks, G. (2003), "Multi-level Governance in the European Union", in Nelsen, B. F. and Stubb, A. (eds.), The European Union: readings on the Theory and Practice of European Integration, New York: Palgrave Macmillan, pp. 298.

52 Ibid, p. 270.

53 Ibid, p. 297.

54 Bache, I. and George, S. (2006), Politics in the European Union, Oxford: Oxford University Press, p. 317.

55 Karluk, R. (2003), Avrupa Birliği ve Türkiye, İstanbul: Beta Yayınları.

56 Bache, I. and George, S. (2006), Politics in the European Union, Oxford: Oxford University Press, p. 318

57 Wincott, D. (2001), “The Court of Justice and the European Policy Process", in Richardson, J. (ed.), European Union: Power and Policy-Making, London and New York: Routledge, p. 182.

58 Preliminary rulings are judgments by the Court on the interpretation of the Treaties or secondary legislation arising from the Treaties.

59 In 1989, the Court of First Instance was created to help the ECJ with the sheer volume of business The Court of First Instance is made up of at least one judge from each member Sstate (27 in 2007). The judges are appointed by agreement of the member state governments for a renewable mandate of six years.

60 Bache, I. and George, S. (2006), Politics in the European Union, Oxford: Oxford University Press, p. 318.

61 The 'constitutionalization' of the Treaty of Rome refers to "the transformation of Community law from a system of conventional international law, which in principle imposes direct obligations on only states, to a new form of law, much more like the internal law of a state" (Wincott, D. (2001), "The Court of Justice and the European Policy Process", in Richardson, J. (ed.), European Union: Power and Policy-Making, London and New York: Routledge, p. 181)

62 Wincott, D. (2001), “The Court of Justice and the European Policy Process”, in Richardson, J. (ed.), European Union: Power and Policy-Making, London and New York: Routledge, p. 182-86.

63 Marks, G., Hooghe, L. and Blank K. (2006), "European Integration from the 1980s: State-Centric vs. Multi-level Governance, in Eilstrup-Sangiovanni M. (ed.), Debates on European Integration: A Reader, New York: Palgrave Macmillan, p. 374.

64 Ibid.

65 Hooghe, L. and Marks, G. (2003), "Multi-level Governance in the European Union", in Nelsen, B. F. and Stubb, A. (eds.), The European Union: Readings on the Theory and Practice of European Integration, New York: Palgrave Macmillan, p. 308-9.

66 Bache, I. and George, S. (2006), Politics in the European Union, Oxford: Oxford University Press, p. 317

67 Greenwood, J. (2003), Interest Representation in the European Union, New York: Palgrave, Macmillan, p. 29-45.

68 Ibid.

69 Ibid.

70 Watson, R. and Shackleton, M. (2003), "Organized Interests and Lobbying in the EU”, in Bomberg, E. and Stubb, A. (eds.), The European Union: How Does It Work?, Oxford: Oxford University Press, p. 89.

71 Greenwood, J. (2003), Interest Representation in the European Union, New York: Palgrave, Macmillan, p. 29-45.

72 Ibid.

73 Ruzza, C. (2002), “ 'Frame Bridging' and the New Politics of Persuasion, Advocacy and Influence”, in Warleigh, A. and Fairbrass, J. (eds.), Influence and Interests in the European Union: The New Politics of Persuasion and Advocacy, the UK and London: Europa Publications Limited, p. 93-110.

74 Ibid, p. 90.

75 George, S. and Bache, I. (2001), Politics in the European Union, New York: Oxford University Press, p. 291.

76 Ibid, p. 123.

77 George, S. and Bache, I. (2001), Politics in the European Union, New York: Oxford University Press, p. 291.

78 Wiener, A. and Diez, T. (2004), European Integration Theory, Oxford: Oxford University Press, p. 117.

79 Hooghe, L. (1996), "Introduction: Reconciling EU-Wide Policy and National Diversity", in Hooghe L. (ed.), Cohesion Policy and European Integration: Building Multi-Level Governance.

80 Wallace, H. and Young, A. R. (1997), Participation and Policy-Making in the European Union, Oxford: Oxford University Press, p. 14.

81 Wiener, A. and Diez, T. (2004), European Integration Theory, Oxford: Oxford University Press, p. 99.

82 Wallace, H. and Young, A. R. (1997), Participation and Policy-Making in the European Union, Oxford: Oxford University Press, p. 21.

83 Eising, R. and Kohler-Koch, B. (1999), "Governance in the European Union: A Comparative Assessment”, in Kohler-Koch, B. and Eising, R. (eds.), The Transformation of Governance in the European Union, London and New York: Routledge, p. 331.

84 Marks, G. (1996), Multi-level Governance and European Integration, United States:Rowman \& Littlefield.

85 Jeffery, C. (2002), “Social and Regional Interests: ESC and Committee of the Regions", in Peterson, J. and Shackleton, M. (eds.), The Institutions of the European Union, Oxford: Oxford University Press, p. 333

86 Eising, R. and Kohler-Koch, B. (1999), “Governance in the European Union: A Comparative Assessment”, in Kohler-Koch, B. and Eising, R. (eds.), The Transformation of Governance in the European Union, London and New York: Routledge.

87 Ibid.

88 Peterson, J. (2004), "Policy Networks", in Wiener, A. and Diez, T., European Integration Theory, Oxford and New York: Oxford University Press, p. 117-33. 89 Hooghe, L. and Marks, G. (2001), Multi-level Governance and European Integration, Lanham, MD: Rowman and Littlefield Publishing.

90 Jeffery, C. (2002), "Social and Regional Interests: ESC and Committee of the Regions", in Peterson, J. and Shackleton, M. (eds.), The Institutions of the European Union, Oxford: Oxford University Press, p. 340.

91 Ibid.

92 Eilstrup-Sangiovanni M. (ed.) (2006), Debates on European Integration: A Reader, New York: Palgrave Macmillan, p. 333.

Vol. 13, No. 1-2, Spring- Summer 2014 
93 Jachtenfuchs, M. and Kohler-Koch, B. (2004), “Governance and Institutional Development”, in Wiener, A. and Diez, T. (eds.), European Integration Theory, Oxford: Oxford University Press, p. 100.

94 Keohane and Stanley, H. (eds.) (1991), “The New European Community: Decisionmaking and Institutional Change”, Boulder, CO: Westview Press.

95 Eising, R. and Kohler-Koch, B. (1999), “Governance in the European Union: A Comparative Assessment”, in Kohler-Koch, B. and Eising, R. (eds.), The Transformation of Governance in the European Union, London and New York: Routledge, p. 269.

96 Wiener, A. and Diez, T. (2004), European Integration Theory, Oxford: Oxford University Press, p. 117.

97 Ibid.

98 Wiener, A. and Diez, T. (2004), European Integration Theory, Oxford: Oxford University Press, p. 133.

99 Ibid.

100 Eising, R. and Kohler-Koch, B. (1999), “Governance in the European Union: A Comparative Assessment”, in Kohler-Koch, B. and Eising, R. (eds.), The Transformation of Governance in the European Union, London and New York: Routledge, p. 285.

101 Ibid.

102 European Union (2000), Lisbon European Council, Presidency Conclusions, Retrieved: May 4, 2007, from World Wide Web: URL

http://www.consilium.europa.eu/ueDocs/cms_Data/docs/pressData/en/ec/00100-r1.en0.htm

103 Ibid.

104 Dale, R. (2004), "Forms of Governance, Governmentality and the EU's Open Method of Coordination", in Larner, W. and Walters, W. (eds.), Global Governmentality: Governing International Spaces, London: Routledge, p.174.

$105 \mathrm{Ibid}$, p. 176.

106 Hodson and Maher, I. (2002), "The Open Method of Coordination as a New Method of Governance: the Case of Soft EU Policy Coordination”, Journal of Common Market Studies, 39(4): 719-746.

107 Jacobsson, K. (2001), “Innovations in EU Governance: the Case of Employment Policy Co-ordination”, SCORE (Stockholm Center for Organizational Research), Research Report, 12

108 Ibid.

109 European Union (2000), Lisbon European Council, Presidency Conclusions, Retrieved: May 4, 2007, from World Wide Web: URL

http://www.consilium.europa.eu/ueDocs/cms_Data/docs/pressData/en/ec/00100-r1.en0.htm

110 Walters, W. and Haahr, J. H. (2005), Governing Europe: Discourse, Governmentality and European Integration, London and New York: Routledge, p. 114.

111 Dale, R. (2004), "Forms of Governance, Governmentality and the EU's Open Method of Coordination", in Larner, W. and Walters, W. (eds.), Global Governmentality: Governing International Spaces, London: Routledge.

112 Walters, W. and Haahr, J. H. (2005), Governing Europe: Discourse, Governmentality and European Integration, London and New York: Routledge, p. 134.

113 Zeitlin, J. and Pochet P. (2005), The Open Method of Coordination in Action: The European Employment and Social Inclusion Strategies, Brussels: P.I.E-Peter Lang S.A.

114 See 2000 Lisbon European Council, Presidency Conclusions, http://www.consilium.europa.eu/ueDocs/cms_Data/docs/pressData/en/ec/00100-r1.en0.htm, (retrieved on May 4, 2007, from World Wide Web: URL).

115 Borras, S. and Jacobsson, K. (2004), "The Open Method of Co-ordination and New Governance Patterns in the EU", Journal of European Public Policy, Vol. 11(2), p. 199 .

116 Pollack, A. (2005), “Theorizing EU Policy-Making”, in Wallace, H. and W, and Pollack, M. A. (eds.), Policy-Making in the European Union, Oxford: Oxford University Press.

117 Hooghe, L. and Marks, G. (200), "Multi-level Goverance in the European Union", in Nelsen, B. F. and Stubb, A. (eds.), The European Union: readings on the Theory and Praactice of European Integration, New York: Palgrave Macmillan, p. 285.

118 Hix, S. (1998), “The Study of the European Union II: The 'New Governance' Agenda and Its Rival”, Journal of European Public Policy, 5 (1), p. 342.

119 Borzel, T. (2010) "European Governance: Negotiation and Competition in the Shadow of Hierarchy", Journal of Common Market Studies, 48(2), 191-219. 